\title{
The effect of intention to act and knowledge of environmental issues on environmental behavior
}

\author{
Fauzul Iman a,1, , Mieke Miarsyah a,2, Diana Vivanti Sigit a,3 \\ a Department of Biology Education, Faculty of Mathematics and Natural Science, Universitas Negeri Jakarta, Jl. Rawamangun Muka, \\ the Special Capital Territory of Jakarta (DKI, Jakarta) 13220, Indonesia \\ 1 fauzuliman04@yahoo.co.id *, 2 mmiarsyah@unj.ac.id, ${ }^{3}$ dianav@unj.ac.id \\ * Corresponding author
}

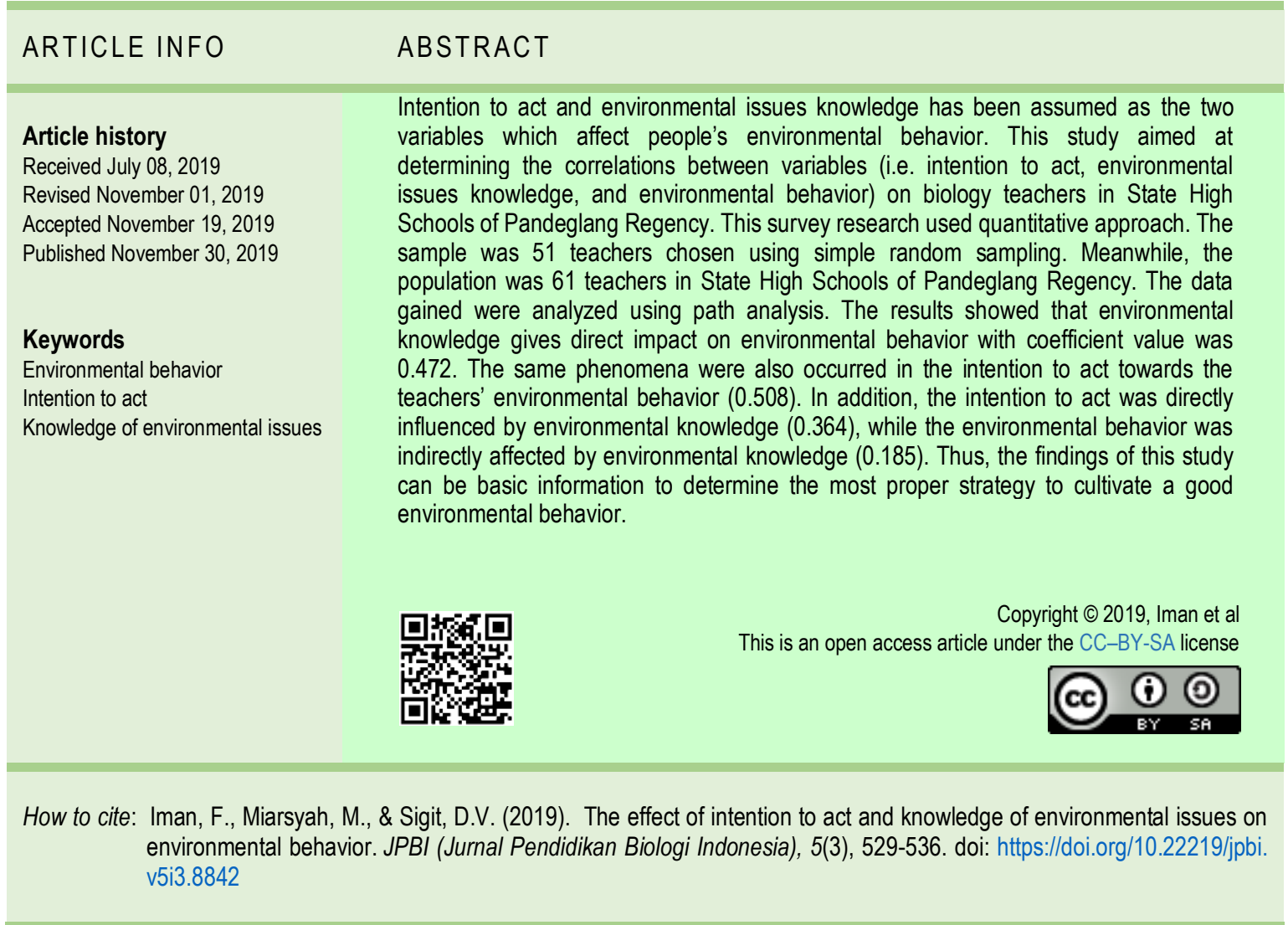

\section{INTRODUCTION}

Nowadays, environmental problems have become a significant problem caused by humans because almost all environmental changes are motivated by human behavior. Namely that unfriendly behavior in the environment extends to the community, to gain personal benefits or pleasures for many members of the community who damage the environment, even though they know the consequences of their actions (Lee, Kim, Kim, \& Choi, 2014; Meyer, 2015; Rood \& Steck, 2019). Many environmental changes occur due to human behavior that does not manage the environment properly (Byerly et al., 2018; Farrow, Grolleau, \& Ibanez, 2017). The environment has changed, where a lot of environmental damage is caused by human activity (Lakoff, 2010; Pe'er, Goldman, \& Yavetz, 2007).

Several previous studies have reported that environmental damage and environmental changes cause 
changes in ecosystem function (Cheng \& Homer, 2015; Kollmuss \& Agyeman, 2002), almost all countries experience this problem. Various factors are indicated as triggers of environmental issues. It appears, such as changes in natural resources, technological changes and development, pollution, and the most important factor is human activity. Human activity is said to be an essential factor because of their role as agents of environmental conservation (Cheng, Wu, \& Huang, 2013; Vaske \& Kobrin, 2001). Human activities or actions, however small they may be, are oriented towards environmental activities.

Education is identified as one of the effective ways to appear in the social-cognitive community. In this case, the teacher should be the essential agent as a pioneer in environmentally sound behavior campaigns. The environmentally sound behavior that is shown continuously, which refers to or is stimulated by the values or norms or criteria contained in the concept of environmental insight (Guerranti, Martellini, Perra, Scopetani, \& Cincinelli., 2019; Marisa \& Brulle, 2003; Schill, Winkel, Diallo, \& Barbarossa, 2019). Teachers who have the opportunity to carry out environmental behavior campaigns are biology teachers because they introduce students to the environmental problems. This is directly the biology teacher is considered master of the environment and environmental issues in this case knowledge of environmental issues (Li, Zhao, Ma, Shao, \& Zhang, 2019; Shi \& Song, 2019; Wang, Zhang, Cao, Duan, \& Hu, 2019). In the end, the teacher knows how to act rationally in behaving environmentally.

The $21^{\text {st }}$ century is also faced with environmental problems that need to be resolved. Environmental changes that occur are caused by humans, not paying attention to environmental damage. Humans in the $21^{\text {st }}$ century need to pay attention to changes in the environment. According to Gkargkavouzi, Halkos, \& Matsiori,

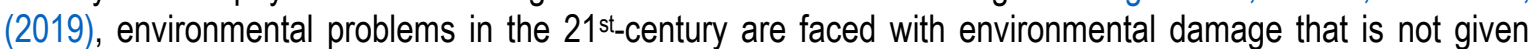
enough attention by humans. Humans only focus on technological developments and do not see adverse effects.

Understanding knowledge of environmental issues is the assessment or opinion of someone in responding to environmental issues (Jannati \& Nazarpour, 2019; Malvestio, Fischer, \& Montaño, 2018). More knowledge about environmental issues that are owned by individuals, the better behavior will be towards to the environment. According to Nakamura, Takahashi, \& Vertinskyc, (2001) which states that behavior models are largely determined by the basic needs of knowledge. Basically, humans will act to protect their needs. It is reinforced by the theory of planning behavior (TPB) intention to act is the feeling of wanting to be influenced by environmental and functional needs of life. According to Brönmark \& Hansson, (2002) that environmental responsibility behavior is determined by various situational factors such as knowledge of environmental issues and intention to act.

However, information that illustrates the pattern of relations between knowledge of environmental issues and the intention to act on environmentally sound behavior has not been widely discussed, but both are considered more partially (Shafii et al., 2019; Yilmaz, Boone, \& Andersen, 2004). This study aimed at determining the correlations between intention to act, environmental issues knowledge, and environmental behavior on biology teachers in State High Schools of Pandeglang Regency. The importance of this research is the results of this study will obtain information related to the relationship between intention to act, environmental issues knowledge, and environmental behavior. The results of this study will be the basis for providing information to humans that intention to act and environmental issues knowledge is essential in the development of human-environmental behavior. In the $21^{\text {st }}$ century, humans need to realize how important intention to act, and environmental issues knowledge are in solving environmental problems.

\section{METHOD}

This study used quantitative descriptive research, namely the type of research that emphasizes testing theories through measuring research variables with numbers and requiring data analysis with statistical procedures. The measuring instrument of this study was in the form of tests and non-tests (questionnaires). This study used path analysis models because, among independent with dependent variables, there are mediating influences. This study consisted of three variables. Namely, the independent variable (knowledge) about environmental issues, intention to act (mediation) while the dependent (dependent) behavior of biology teachers is environmentally sound.

This research was conducted in-State High Schools in Banten Province academic year of 2018/2019. The target population in this study were all biology teachers in Banten Province. In contrast, affordable populations in this study only used a sample of Biology educators in Pandeglang District High School as many as 51 educators. The path analysis design is explained in Figure 1. 
Data collection techniques in this study were carried out in the form of scores on biology teacher behavior variables with environmental insight, knowledge of environmental issues, and intention to act. The tool used was divided into two types, namely test and non-test, a multiple-choice test measuring instruments to measure knowledge of environmental issues. In contrast, non-test measuring instruments were in the form of questionnaires to measure the intention to act and environmentally friendly biology teacher behavior.

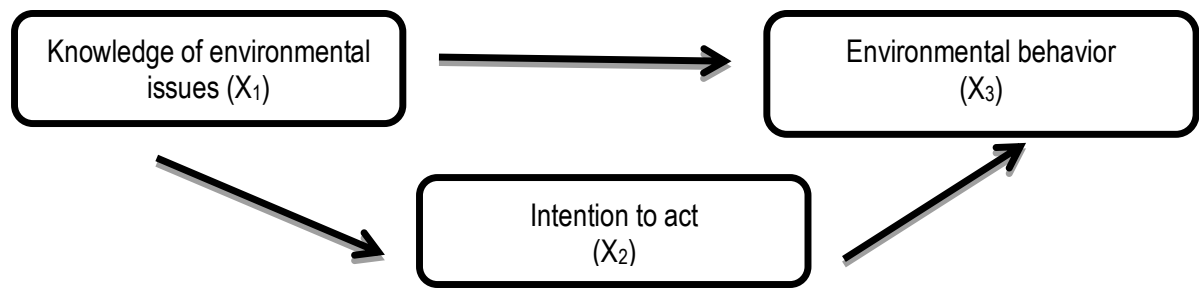

Figure 1. Path analysis

Knowledge instruments on environmental issues are used aspects of knowledge, namely: (1) factual knowledge, (2) conceptual knowledge, (3) procedural knowledge; (4) metacognitive knowledge about climate change, environmental pollution, environmental destruction, biodiversity (Bian, Inyang, Daniels, Otto, \& Struthers, 2010; Pimentel et al., 2004). The instrument of intention to act using the dimension of the desire to protect the environment, the desire to preserve the environment, the desire to utilize natural resources, whereas environmentally sound behavioral instruments used the renewable, substitution, interdependency, adaptation dimensions.

The knowledge instrument was validated with biserial point formula and reliability. While the intention-to-act instrument and environmentally friendly biology teacher behavior were validated with the pearson product moment formula and reliability with the cronbach alpha formula. Prerequisite tests used the kolmogorovsmirnov normality test $(\alpha=0.05)$ using the SPSS 22.0 program, and the homogeneity test used one-way anova analysis test technique. Test of significance and linearity regression used the F-test, calculation of the correlation coefficient using the moment of pearson products. The results of the significance test of the correlation coefficient with the t-test were continued using path analysis.

\section{RESULTS AND DISCUSSION}

The results of Kolmogorov-Smirnov normality on the environmental issue knowledge variable (X1) are 0.200 . In contrast, the significance value of the intention to act (X2) variable and the environmentally friendly biology teacher behavior were 0.200 and 0.154 , respectively. Thus, the significance of the three variables (> 0.05 ) can be concluded that the data came from populations that are normally distributed. Based on the results of data calculations to compile a model of the regression equation between knowledge of environmental issues and intention to act in the sequence 126,089 and 0,527 . The regression equation between the personality variable and the intention to act is X2 $=126,089+0,527$ X1. Regression calculation between knowledge of environmental issues and intention to act can be seen in Table 1.

Table 1. The results of the regression equation between knowledge of environmental issues and intention to act

\begin{tabular}{llccccc}
\hline \multirow{2}{*}{ Model } & \multicolumn{2}{c}{ Unstandardized coefficients } & Standardized coefficients & \multirow{2}{*}{ S } & Sig. \\
\cline { 2 - 6 } & $\mathbf{B}$ & Std. error & Beta & & 48.566 & .000 \\
\hline 1 & 126.089 & 2.596 & .364 & 2.734 & .009 \\
\hline $\begin{array}{l}\text { (Constant) } \\
\begin{array}{l}\text { Knowledge of environmental } \\
\text { issues }\end{array}\end{array}$ & .527 & .193 & & .009 \\
\hline
\end{tabular}

Based on Table 2, the regression equation between knowledge of environmental issues and environmentally sound behavior (REB) is $X 3=72.381+0.664 \mathrm{X} 1$. The coefficient shows that the equation can be trusted because it has a significance value $(>0.05)$. At the same time, the regression between the intentions to act towards environmentally sound behavior (REB) (Table 3 ) is written with the equation $\mathrm{X} 3=$ $15.421+0.493 \times 2$ with a significance value $(>0.05)$. These results indicate that attention to act affects environmentally sound behavior (REB). 
Based on the results of the significance test, the regression line equation between knowledge of environmental issues and intention to act shows the calculated value of 2.734 with a significance value of 0.009 . Thus, equality is a significant variable or shows the influence of knowledge of environmental issues on the intention to act. Similar results are also shown for the regression equation of the environmental problems knowledge on environmentally sound behavior (REB) (X1 against $X 3$ ) and intention to act on REB's environmentally sound behavior (X2 against X3).

Table 2. The results of the regression equation between knowledge of environmental issues and environmentally sound behavior

\begin{tabular}{llcccccc}
\hline \multirow{2}{*}{ Model } & \multicolumn{2}{c}{ Unstandardized coefficients } & Standardized coefficients & \multirow{2}{*}{$\mathbf{t}$} & \multirow{2}{*}{ Sig. } \\
\cline { 3 - 6 } & B & Std. error & Beta & & & \\
\hline \multirow{2}{*}{1} & (Constant) & 72.381 & 2.385 & & & 0.352 & .000 \\
& Knowledge of environmental issues & .664 & .177 & .472 & 3.748 & .000 \\
\hline
\end{tabular}

Table 3. The results of the regression equation between intention to act and environmentally sound behavior

\begin{tabular}{cccccccc}
\hline & \multirow{2}{*}{ Model } & \multicolumn{2}{c}{ Unstandardized coefficients } & Standardized coefficients & \multirow{2}{*}{ t } & \multirow{2}{*}{ Sig. } \\
\cline { 3 - 6 } & B & Std. error & Beta & & .971 & .336 \\
& (Constant) & 15.421 & 15.883 & .508 & 4.130 & .000 \\
\hline
\end{tabular}

Testing the significance of knowledge equality in environmental issues on environmentally sound behavior (REB) shows a value of 3.748 with a consequence of 0,000 , while the value calculated for the equality of intention to act against REB is 4.130 with a significance of 0,000 . These results indicate that there is a significant relationship between knowledge of environmental issues with environmentally sound behavior (REB), as well as the relationship between intention to act and environmentally sound behavior (REB). The results of the calculation of the correlation test between variables in this study obtained data as in Table 4.

Table 4. Simple correlation coefficient between variables

\begin{tabular}{cccc}
\hline \multirow{2}{*}{ Matrix } & \multicolumn{3}{c}{ Coefficient of correlation $(\alpha=0,00)$} \\
\cline { 2 - 4 } & $\mathbf{X}_{1}$ & $\mathbf{X}_{2}$ & $\mathbf{X}_{3}$ \\
\hline$X_{1}$ & 1 & 0,364 & 0,508 \\
$X_{2}$ & & 1 & 1 \\
$X_{3}$ & & & 1 \\
\hline
\end{tabular}

The correlation coefficient matrix between variables found a correlation between knowledge of environmental issues and intention to act was $\mathrm{R} 1,2=0.364$, while the correlation between intention to act and REB was R2.3 $=0.508$. After each correlation coefficient is obtained, the next step is to calculate the path coefficient. Direct and indirect effects explained to Table 5.

Table 5. The results of the calculation of direct and indirect effects

\begin{tabular}{|c|c|c|c|c|c|}
\hline \multirow{2}{*}{ Direct or indirect } & \multirow{2}{*}{$\mathrm{n}$} & \multirow{2}{*}{ Path coefficient } & \multirow{2}{*}{ t-count } & \multicolumn{2}{|c|}{$\mathrm{t}$-table } \\
\hline & & & & 0.05 & 0.01 \\
\hline$X_{1}$ on $X_{3}$ & 51 & 0,472 & $3,748^{\star *}$ & 2,0085 & 2,6777 \\
\hline$X_{2}$ on $X_{3}$ & 51 & 0,508 & $4,130^{\star *}$ & 2,0085 & 2,6777 \\
\hline$X_{1}$ on $X_{2}$ & 51 & 0,364 & $2,734^{\star *}$ & 2,0085 & 2,6777 \\
\hline$X_{1}$ on $X_{3}$ through $X_{2}$ & 51 & 0,185 & $3,116^{\star *}$ & 2,0085 & 2,6777 \\
\hline
\end{tabular}

Based on the results of the correlation test in Table 5 , knowledge variables on environmental issues and intention to act 0.364 with a significance value $(<0.05)$, so that the correlation between knowledge of environmental issues and the intention to act is significant. Meanwhile, the path analysis coefficient shows that t-count values (2.734)>t table (2.6777) so that the intention to act variable is directly influenced positively by knowledge of environmental issues. These results indicate that knowledge of positive environmental issues shows the tendency of biology teachers to act positively on the environment better. The results of a metaanalysis of studies on aspects of environmental behavior found that environmental behavior is positively correlated with the level of understanding of individuals for environmental problems (Anderson \& Bateman, 2017; Marsh \& Bugusu, 2007). People with adequate conservation knowledge tend to do more tasks such as recycling waste and are willing to devote themselves to the task of environmental protection (Ajzen, 2011; Schultz, 2002). 
The results of the correlation coefficient of intention to act on environmentally sound behavior (REB) show the same results as the correlation between knowledge of environmental issues and the intention to act. Based on the results of the coefficient calculation (Table 5) shows that $t$-count values $(4,130)>t$-table (2.6777). These results indicate that the behavior of biology teachers with environmental insight is positively influenced by the intention to act. The desire to act someone becomes a determinant in behaving towards the environment (Farrow et al., 2017; Lakoff, 2010). Environmental knowledge influences behavioral intentions positively and influences environmental sensitivity and environmental responsibility (Kollmuss \& Agyeman, 2002; Marisa \& Brulle, 2003; Vaske \& Kobrin, 2001).

However, the path coefficient of the indirect influence of the knowledge variable on environmentally sound behavior (REB) is 0.185 . These results indicate that knowledge of environmental issues does not directly affect the behavior of biology teachers with environmental insight but through the intention to act. Contextually, it can be said that if the teacher has positive knowledge of environmental issues, indirectly, the teacher has environmentally sound behavior because they have the intention to act well. According to Guerranti et al., (2019), showing that environmental knowledge correlates with environmental actions.

The Theory of Reasoned Action (TRA) explains that intention to act is a representation of knowledge (Malvestio et al., 2018; Shafii et al., 2019). The formation of environmentally sound behavior was supported by three components that were very difficult to separate, namely: knowledge, feelings, and desires to act (Pimentel et al., 2004; Yilmaz et al., 2004). Therefore, the results of this study can be used as reinforcement concepts that have been trusted. However, it is necessary to develop knowledge factors for more specific environmental issues that have the most significant influence on the behavior of environmentally friendly biology teachers.

Environmental knowledge is a set of ecological knowledge possessed by individuals about the environment. Environmental knowledge is a basic knowledge owned by a person about things that can be done to assist in environmental protection activities (Profitiliotis \& Loizidou, 2019; Stafford \& Jones, 2019). Knowledge about the environment can affect a person's attitude. The higher the level of environmental knowledge and attention possessed by a person, the higher the ecological attitude possessed by a person compared to someone who does not have knowledge and attention to the environment, which in turn influences their ecological behavior (Lamnatou \& Chemisana, 2017; Saud, Gelcich, \& Barraza, 2018). The better environmental knowledge possessed by someone, the more someone will know about the quality of environmentally friendly so that it will increase their motivation to develop environmentally-friendly (Gay \& Sánchez, 2019; Jia, Soucie, Alisat, Curtin, \& Pratt, 2017).

There are four environmentally friendly behaviors, namely how often to bring food from home, how often to bring water bottles (not bottles) from home, how often to put trash in its place, and how often to separate organic and inorganic waste (Bancheva, 2019; Julinová, Vaňharová, \& Jurča, 2018). Of the four behaviors, putting rubbish in place gets the highest value, followed by bringing his own drinking water bottle from home, bringing his own food from home, and the low one is sorting out organic and inorganic waste (O'Neill, 2017; Seredkin, Zabolotsky, \& Jeffress, 2016).

Three factors are indicators of environmental attitudes: (1) environmental protection, namely the practice of protecting the natural environment at the individual, organizational or government level, for the benefit of the environment and humans; (2) the role of the government, namely the government which has the authority to regulate and develop policies in the framework of managing or controlling matters relating to environmental management; and (3) personal norms, namely acts of concern for the environment, which are based on own principles adopted by consumers (Sancha, Wong, \& Thomsen, 2016). These different principles result in different points of view on green products, government regulations, and environmental problems.

Environmental problems related to understanding, attitude, and behavior are subjective because each student has a different level of environmental knowledge. Students' perceptions of the existing environmental conditions will also differ according to their understanding and awareness (Missimer \& Maliva, 2018). At this time, the world needs people who are aware of the environment, that is, people who have understood and applied attitudes and behaviors that care about the environment and apply the principles of ecology and environmental ethics (Dai, Bergot, Liang, Xiang, \& Huang, 2015).

Environmental attitudes are based more on personal principles adopted by someone, and the extent to which an individual feels himself to be an integrated part of the environment. Environmentally friendly consumer behavior is characterized by attitudes and actions to protect the environment, which are based on green products. 


\section{CONCLUSION}

The results of the study have shown that there is a direct influence between knowledge of environmental issues and the intention to act on the behavior of biology teachers with environmental insight. Meanwhile, knowledge of environmental issues influences the behavior of biology teachers with environmental insight indirectly through the intention to act. Based on the results of the study, systematic efforts are needed to improve teacher behavior towards the environment through environmentally sound school organizations. It means that the teacher can appear knowledge and intention to act on the environment.

\section{ACKNOWLEDGMENT}

Our highest appreciation is addressed to all parties involved in this study. This research hopefully contributes to the development of knowledge, especially related to environmental topics.

\section{REFERENCES}

Ajzen, I. (2011). The theory of planned behaviour: Reactions and reflections. Journal Psychology \& Health, 26(9), 1113-1127. doi: https://doi.org/10.1080/08870446.2011.613995

Anderson, L. M., \& Bateman, T. S. (2017). Individual environmental initiative: Championing natural environmental issues in U.S. business organizations. Academy of Management Journal, 43(4). doi: https://doi.org/10.5465/1556355

Bancheva, A. (2019). A bibliometric analysis of global research on the arctic (With special interest in environmental issues). Polar Science, 21, 233-237. doi: https://doi.org/10.1016/j.polar.2019.04.002

Bian, Z., Inyang, H. I., Daniels, J. L., Otto, F., \& Struthers, S. (2010). Environmental issues from coal mining and their solutions. Mining Science and Technology, 20(2), 215-223. doi: https://doi.org/10.1016/S1674 $-5264(09) 60187-3$

Brönmark, C., \& Hansson, L. A. (2002). Environmental issues in lakes and ponds: Current state and perspectives. Journal Environmental Conservation, 29(3), 290-307. doi: https://doi.org/10.1017/S03768 92902000218

Byerly, H., Balmford, A., Ferraro, P. J., Wagner, C. H., Palchak, E., Polasky, S., ... Fisher, B. (2018). Nudging pro-environmental behavior: Evidence and opportunities. Frontiers in Ecology and the Environment, 16(3), 159-168. doi: https://doi.org/10.1002/fee.1777

Cheng, T. M., \& Homer, C. W. (2015). How do environmental knowledge, environmental sensitivity, and place attachment affect environmentally responsible behavior? An integrated approach for sustainable island tourism. Journal of Sustainable Tourism, 23(4), 557-576. doi: https://doi.org/10.1080/09669582.2014.9 65177

Cheng, T. M., Wu, H. C., \& Huang, L. M. (2013). The influence of place attachment on the relationship between destination attractiveness and environmentally responsible behavior for island tourism in Penghu, Taiwan. Journal of Sustainable Tourism, 21(8), 1166-1187. doi: https://doi.org/10.1080/096695 82.2012 .750329

Dai, K., Bergot, A., Liang, C., Xiang, W. N., \& Huang, Z. (2015). Environmental issues associated with wind energy - a review. Renewable Energy, 75, 911-921. doi: https://doi.org/10.1016/j.renene.2014.10.074

Farrow, K., Grolleau, G., \& Ibanez, L. (2017). Social norms and pro-environmental behavior: A review of the evidence. Ecological Economics, 140, 1-13. doi: https://doi.org/10.1016/j.ecolecon.2017.04.017

Gay, J. S., \& Sánchez, L. E. (2019). Mainstreaming environmental issues into housing plans: The approach of strategic environmental assessment. Environmental Impact Assessment Review, 77, 145-153. doi: https://doi.org/10.1016/j.eiar.2018.12.005

Gkargkavouzi, A., Halkos, G., \& Matsiori, S. (2019). Environmental behavior in a private-sphere context: Integrating theories of planned behavior and value belief norm, self-identity and habit. Resources, Conservation and Recycling, 148, 145-156. doi: https://doi.org/10.1016/j.resconrec.2019.01.039

Guerranti, C., Martellini, T., Perra, G., Scopetani, C., \& Cincinelli., A. (2019). Microplastics in cosmetics: environmental issues and needs for global bans. Environmental Toxicology and Pharmacology, 68, 7579. doi: https://doi.org/10.1016/j.etap.2019.03.007

Jannati, J., \& Nazarpour, D. (2019). Optimal performance of electric vehicles parking lot considering 
environmental issue. Journal of Cleaner Production, 206(1), 1073-1088. doi: https://doi.org/10.1016/j.j clepro.2018.09.222

Jia, F., Soucie, K., Alisat, S., Curtin, D., \& Pratt, M. (2017). Are environmental issues moral issues? Moral identity in relation to protecting the natural world. Journal of Environmental Psychology, 52, 104-113. doi: https://doi.org/10.1016/j.jenvp.2017.06.004

Julinová, M., Vaňharová, L., \& Jurča, M. (2018). Water-soluble polymeric xenobiotics - polyvinyl alcohol and polyvinylpyrrolidon - and potential solutions to environmental issues: A brief review. Journal of Environmental Management, 228, 213-222. doi: https://doi.org/10.1016/j.jenvman.2018.09.010

Kollmuss, A., \& Agyeman, J. (2002). Mind the gap: Why do people act environmentally and what are the barriers to pro-environmental behavior? Environmental Education Researc, 8(3), 239-260. doi: https://d oi.org/10.1080/13504620220145401

Lakoff, G. (2010). Why it matters how we frame the environment. Environmental Communication, 4(1), 70-81. doi: https://doi.org/10.1080/17524030903529749

Lamnatou, C., \& Chemisana, D. (2017). Photovoltaic/thermal (PVT) systems: A review with emphasis on environmental issues. Renewable Energy, 105, 270-287. doi: https://doi.org/10.1016/j.renene.2016.12. 009

Lee, Y. ki, Kim, S., Kim, M. seong, \& Choi, J. gu. (2014). Antecedents and interrelationships of three types of pro-environmental behavior. Journal of Business Research, 67(10), 2097-2105. doi: https://doi.org/10. 1016/j.jbusres.2014.04.018

Li, D., Zhao, L., Ma, S. huang, Shao, S., \& Zhang, L. (2019). What influences an individual's proenvironmental behavior? A literature review. Resources, Conservation and Recycling, 146, 28-34. doi: https://doi.org/10.1016/j.resconrec.2019.03.024

Malvestio, A. C., Fischer, T. B., \& Montaño, M. (2018). The consideration of environmental and social issues in transport policy, plan and programme making in Brazil: A systems analysis. Journal of Cleaner Production, 179(1), 674-689. doi: https://doi.org/10.1016/j.jclepro.2017.11.152

Marisa, D. J., \& Brulle, R. (2003). Media's social construction of environmental issues: Focus on global warming - a comparative study. International Journal of Sociology and Social Policy, 23(10), 74-105. doi: https://doi.org/10.1108/01443330310790327

Marsh, K., \& Bugusu, B. (2007). Food packaging-Roles, materials, and environmental issues. Journal of Food Science, 72(3), 39-55. doi: https://doi.org/10.1111/j.1750-3841.2007.00301.x

Meyer, A. (2015). Does education increase pro-environmental behavior? Evidence from Europe. Ecological Economics, 116, 108-121. doi: https://doi.org/10.1016/j.ecolecon.2015.04.018

Missimer, T. M., \& Maliva, R. G. (2018). Environmental issues in seawater reverse osmosis desalination: Intakes and outfalls. Desalination, 434, 198-215. doi: https://doi.org/10.1016/j.desal.2017.07.012

Nakamura, M., Takahashi, T., \& Vertinskyc, I. (2001). Why Japanese firms choose to certify: A study of managerial responses to environmental issues. Journal of Environmental Economics and Management, 42(1), 23-52. doi: https://doi.org/10.1006/jeem.2000.1148

O'Neill, T. A. (2017). Protection of antarctic soil environments: A review of the current issues and future challenges for the environmental protocol. Environmental Science \& Policy, 76, 153-164. doi: https://doi.org/10.1016/j.envsci.2017.06.017

Pe'er, S., Goldman, D., \& Yavetz, B. (2007). Environmental literacy in teacher training: Attitudes, knowledge, and environmental behavior of beginning students. The Journal of Environmental Education, 39(1), 4559. doi: https://doi.org/10.3200/JOEE.39.1.45-59

Pimentel, D., Berger, B., Filiberto, D., Newton, M., Wolfe, B., Karabinakis, E., ... Nandagopal, S. (2004). Water resources: Agricultural and environmental issues. BioScience, 54(10), 909-918. doi: https://doi. org/10.1641/0006-3568(2004)054[0909:WRAAEI]2.0.CO;2

Profitiliotis, G., \& Loizidou, M. (2019). Planetary protection issues of private endeavors in research, exploration, and human access to space: An environmental economics approach to backward contamination. Space Policy, 50. doi: https://doi.org/10.1016/j.spacepol.2019.08.002

Rood, E. C. S., \& Steck, M. K. (2019). Behaviour shapes environmental variation and selection on learning and plasticity: Review of mechanisms and implications. Animal Behaviour, 147, 147-156. doi: https:// doi.org/10.1016/j.anbehav.2018.08.007

Sancha, C., Wong, C. W. Y., \& Thomsen, C. G. (2016). Buyer-supplier relationships on environmental issues: A contingency perspective. Journal of Cleaner Production, 112(3), 1849-1860. doi: https://doi.org/10.10 16/j.jclepro.2014.09.026 
Saud, G., Gelcich, S., \& Barraza, J. (2018). Marine environmental issues in the mass media: Insights from television, newspaper and internet searches in chile. Ocean \& Coastal Management, 165, 154-160. doi: https://doi.org/10.1016/j.ocecoaman.2018.08.015

Schill, M., Winkel, D. G., Diallo, M. F., \& Barbarossa, C. (2019). Consumers' intentions to purchase smart home objects: Do environmental issues matter? Ecological Economics, 161, 176-185. doi: https://doi. org/10.1016/j.ecolecon.2019.03.028

Schultz, P. W. (2002). New environmental theories: Empathizing with nature: The effects of perspective taking on concern for environmental issues. Journal of Social Issues, 56(3), 391-406. doi: https://doi.org/10. $1111 / 0022-4537.00174$

Seredkin, M., Zabolotsky, A., \& Jeffress, G. (2016). In situ recovery, an alternative to conventional methods of mining: Exploration, resource estimation, environmental issues, project evaluation and economics. Ore Geology Reviews, 79, 500-514. doi: https://doi.org/10.1016/j.oregeorev.2016.06.016

Shafii, N. Z., Saudi, A. S. M., Pang, J. C., Abu, I. F., Sapawe, N., Kamarudin, M. K. A., \& Saudi, H. F. M. (2019). Application of chemometrics techniques to solve environmental issues in Malaysia. Heliyon, 5(10). doi: https://doi.org/10.1016/j.heliyon.2019.e02534

Shi, X., \& Song, Z. (2019). The silent majority: Local residents' environmental behavior and its influencing factors in coal mine area. Journal of Cleaner Production, 240. doi: https://doi.org/10.1016/j.jclepro.201 9.118275

Stafford, R., \& Jones, P. J. S. (2019). We should not separate out environmental issues, but the current approach to plastic pollution can be a distraction from meaningful action. A response to Avery-Gomm et al. Marine Policy, 107. doi: https://doi.org/10.1016/j.marpol.2019.103585

Vaske, J. J., \& Kobrin, K. C. (2001). Place attachment and environmentally responsible behavior. The Journal of Environmental Education, 32(4), 16-21. doi: https://doi.org/10.1080/00958960109598658

Wang, C., Zhang, J., Cao, J., Duan, X., \& Hu, Q. (2019). The impact of behavioral reference on tourists' responsible environmental behaviors. Science of The Total Environment, 694. doi: https://doi.org/10.10 16/j.scitotenv.2019.133698

Yilmaz, O., Boone, W. J., \& Andersen, H. O. (2004). Views of elementary and middle school Turkish students toward environmental issues. International Journal of Science Education, 26(12). doi: https://doi.org/ $10.1080 / 0950069042000177280$ 